\title{
STUDY OF PROTEIN CONTENT AND EFFECT OF pH VARIATION ON SOLUBILITY OF SEED PROTEIN OF ELEUSINE CORACANA (VARIETY DFM-1 AND HR-374)
}

\author{
Sangeeta Gupta ${ }^{1}$, S.K. Shrivastava ${ }^{2}$, Manjul Shrivastava ${ }^{3}$ \\ ${ }^{1,2}$ Department of Applied Chemistry, Jabalpur Engineering College, Jabalpur-482011(M.P.) India \\ ${ }^{3}$ Department of Chemistry Govt. M.H. College of Home Science \&, Science for Women Jabalpur (M.P.) India
}

\begin{abstract}
Protein utilization in the different food systems principally depend on their functional properties. The solubility behavior of the seed protein is of great importance from the several points of view. It determines their utility for many industrial purposes. Solubility is a critical functional property, since a protein generally has to be in solution in order to exert its other desirable functional characteristics. Nitrogen Solubility Index and Protein Dispersibility Index (PDI) are the two most common methods of evaluating solubility characteristics. Hence in this study seeds of Eleusine coracana (variety DFM-1 and HR-374) minor millet were studied for protein solubility at wide range of pH from 0.5 to 13.5 .
\end{abstract}

Keywords: Protein solubility, Protein Dispersibility Index, Nitrogen Solubility Index, Minor millet Seeds, Variety of Eleusine coracana.

\section{INTRODUCTION}

Millets are staple foods that supply a major portion of calories and protein to large segments of populations in the semi-arid tropical regions of Africa and Asia. Finger millet (Eleusine coracana) is the primary food source for millions of people in tropical dry land regions. It also has nutritional qualities superior to that of rice and is on par with wheat. It is also known as Finger millet or Ragi in India [1-2].

Nutritional and functional qualities of protein are largely determined by its amino acid content and nitrogen solubility. Nitrogen solubility is one aspect of hydration which is the most important characteristics in evaluating protein quality since many functional properties of protein depend upon their capacity to go into solution initially. Solubility is affected by many factors such as $\mathrm{pH}$ during extraction or solubilization, size of meal particle, temperature and meal solvent ratio, composition of solvent and character of protein [3].

\section{MATERIALS AND METHODS}

New hybrid, authentic, healthy and matured seeds of minor millets variety Eleusine coracana (variety DFM-1 \& HR-374), under investigation were procured from Agriculture Research Station Dindori, regional extention of Jawaharlal Nehru Krishi Vishwavidyalaya, Jabalpur (M.P.).

In the present investigation the seeds of Eleusine coracana (variety DFM-1 \& HR-374) minor millet were analyzed for their protein content and protein solubilization with $\mathrm{pH}$ variation in the powdered form, because size of seed powder has been shown to influence the nitrogenous extraction $[4,5]$. The seeds were sun dried and powdered to 60 meshes [6].

The effect of $\mathrm{pH}$ variation of the extractant on the protein solubilization were studied by varying $\mathrm{pH}$ of water, ranging from 0.5 to 13.5 , brought by addition of hydrochloric acid or sodium hydroxide solution. One gram of the seed powder was suspended in $20 \mathrm{ml}$ of extractant of desired $\mathrm{pH}$. The contents were shaken in electrical shaker for about 2 hours at room temperature and centrifuged for 20 minutes at $2000 \mathrm{rpm}$ in a centrifuge. The nitrogen solubilized was determined in supernatant so obtained by Semi-Micro Kjeldahl method [7].

\section{RESULTS AND DISCUSSION}

The seeds of Eleusine coracana (variety DFM-1 \& HR-374) were studied for their protein solubility behaviors in considerable wide $\mathrm{pH}$ range from 0.5 to 13.5 .The results of protein solubility are given in Table 1 . These results are also graphically represented in Figure 1.1 to 1.2.

The determination of percent of total proteins (12.25 percent) of Eleusine coracana variety DFM-1 solublized showed the maximum solubility (6.95 percent) at $\mathrm{pH} 12.0$, while it was minimum (1.39 percent) at $\mathrm{pH} 2.0$. At the remaining $\mathrm{pH}$, solubility of the proteins was found to fluctuate between 1.405-4.84 percent. 
The solubility of total seed proteins (11.66 percent) of Eleusine coracana variety HR-374 was found to be maximum (6.36 percent) at $\mathrm{pH} 12.0$ and it was observed to be minimum ( 0.795 percent $)$ at $\mathrm{pH} 2.0$. The solubility of the proteins was found to fluctuate between 1.14-4.25percent at the remaining $\mathrm{pH}$.

It was found that alkaline medium were more effective in extraction of protein from minor millets. As the acidity was increased, solubility drastically reduced rapidly and minimum is observed. This is isoelectric region.

\section{CONCLUSIONS}

Eleusine coracana (variety DFM-1 \& HR-374) millets are fair sources of protein and protein quality is comparable to other millet proteins. In populations consuming these minor millets as staple food, these millets can contribute nearly $90 \%$ of their protein requirement at the present rate of consumption. Protein utilization in the different food systems principally depend on their functional properties. The solubility behavior of the seed protein is of great importance from the several points of view. It determines their utility for many industrial purposes and finds potential application in food products such as soups, beverage and food cakes, in which gelatin, emulsification and foaming properties are required.

\section{REFERENCES}

[1] S Ignacimuthu and S Antony Ceasar, "Development of transgenic finger millet (Eleusine coracana (L.)Gaertn.) resistant to leaf blast disease", J. Biosci., Indian Academy of Sciences Vol. 37, No.1,pp. 1-13, 1March 2012.

[2] Majumder, T.K., K.S. Premavalli and Bawa, A.S., "Effect of puffing on calcium and iron contents of ragi varieties and their utilization", J. Food Sci.Technol., vol.42, No. 5, pp. 542-545, 2006.

[3] Ingale S. and Shrivastava S.K., "Study of Solublity Behaviour of Some New Varieties of Oil Seeds",Asian Journal of Chemistry, Vol.225,pp. 4130-4132, 2010.

[4] Dijang S.T., H.A. Lillevik and C.D. Ball, Cereal Chem., Vol.30, pp. 230, 1953.

[5] Dijang S.T., H.A. Lillevik and C.D. Ball, Arch. Bio. Chem. Biophys., vol.40, pp. 165, 1952.

[6] Nagraj, G., "Quality and Utility of Oil Seeds, Directorate of Oil Seeds Research (ICRA) Hyderabad," India, 1995.

[7] Pearson,D., Laboratory Techniques in Food Analysis, London, Butter Worths, pp. 54-55,1973.

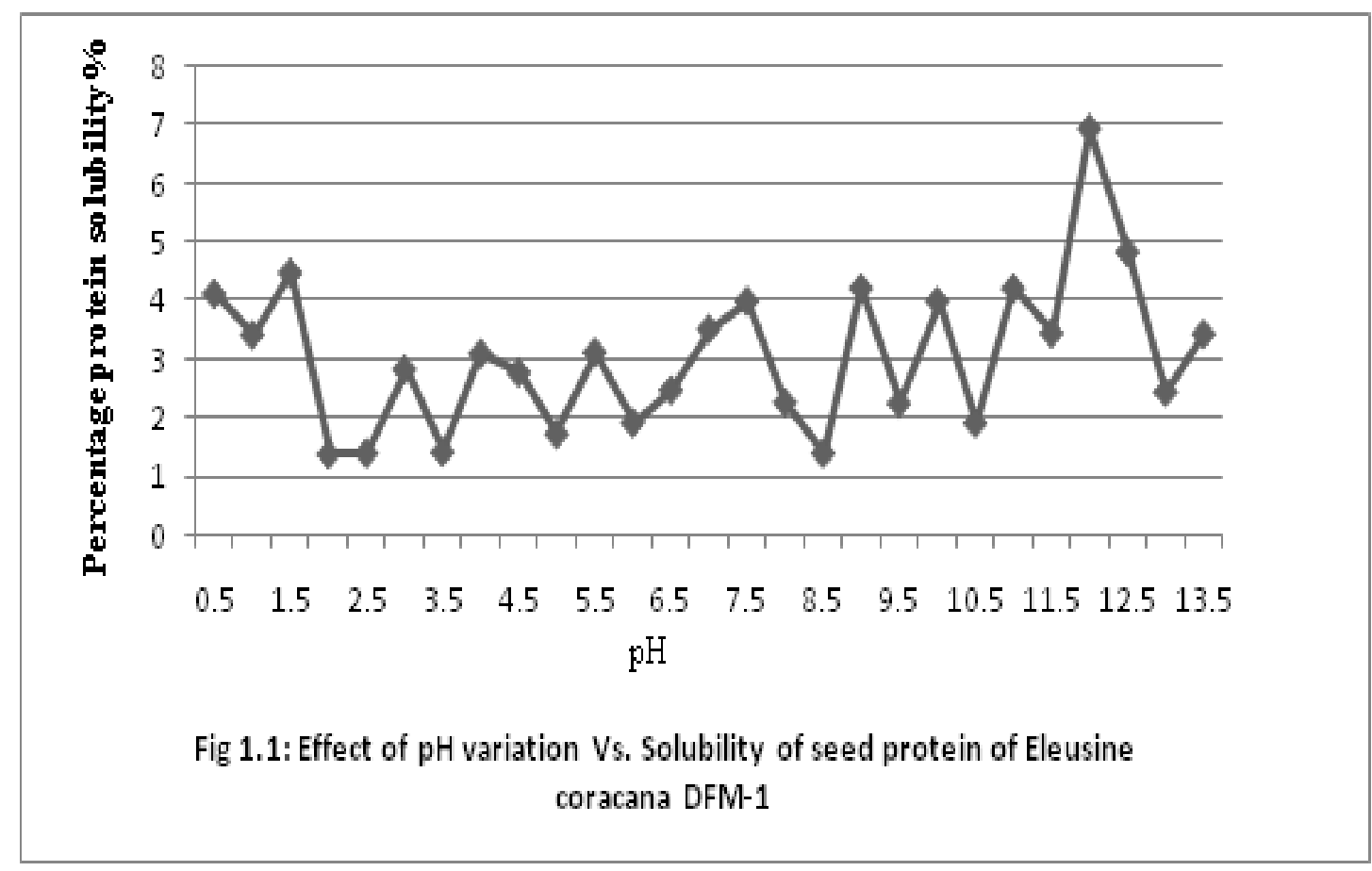




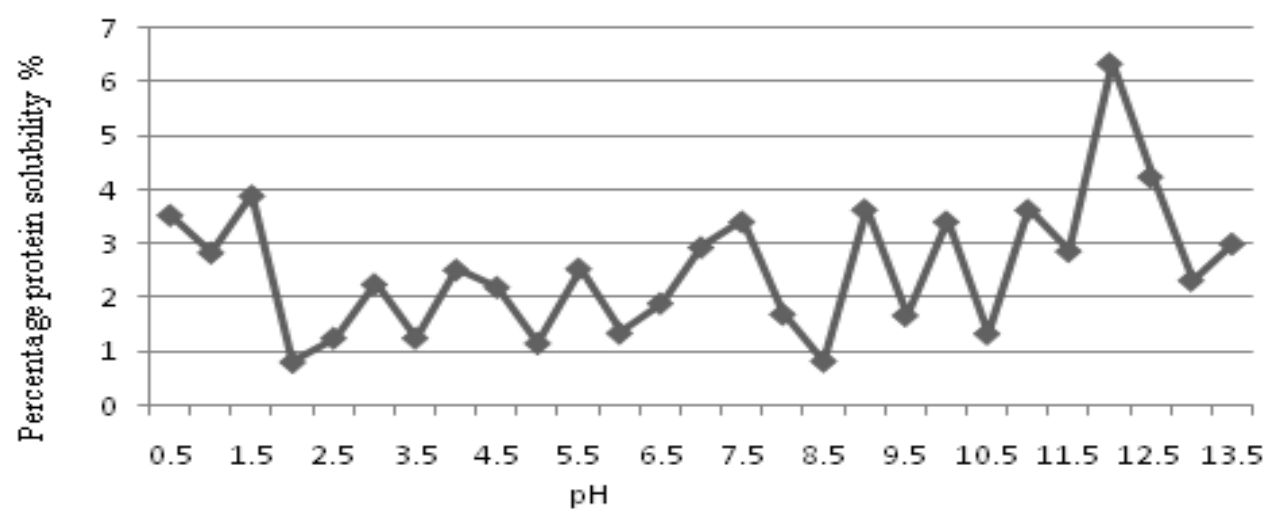

Fig 1.2: Effect of pH variation Vs. Solubility of seed protein of Eleusine coracana HR-374

Table1. The effect of $\mathrm{pH}$ variation on the solubility of seed proteins of Eleusine coracana (Variety DFM-1\&HR-374)

\begin{tabular}{|l|l|l|}
\hline $\mathrm{pH}$ Value & $\begin{array}{l}\text { Eleusine coracana } \\
\text { DFM-1 }\end{array}$ & $\begin{array}{l}\text { Eleusine coracana } \\
\text { HR-374 }\end{array}$ \\
\hline 0.5 & 4.125 & 3.535 \\
\hline 1.0 & 3.425 & 2.835 \\
\hline 1.5 & 4.485 & 3.895 \\
\hline 2.0 & 1.385 & 0.795 \\
\hline 2.5 & 1.405 & 1.242 \\
\hline 3.0 & 2.835 & 2.245 \\
\hline 3.5 & 1.425 & 1.242 \\
\hline 4.0 & 3.105 & 2.515 \\
\hline 4.5 & 2.782 & 2.191 \\
\hline 5.0 & 1.731 & 1.144 \\
\hline 5.5 & 3.125 & 2.535 \\
\hline 6.0 & 1.925 & 1.335 \\
\hline 6.5 & 2.482 & 1.890 \\
\hline 7.0 & 3.525 & 2.935 \\
\hline 7.5 & 4.00 & 3.411 \\
\hline 8.0 & 2.272 & 1.688 \\
\hline 8.5 & 1.405 & 0.815 \\
\hline 9.0 & 4.225 & 3.635 \\
\hline 9.5 & 2.255 & 1.665 \\
\hline 10.0 & 4.00 & 3.411 \\
\hline 10.5 & 1.9155 & 1.325 \\
\hline 11.0 & 4.221 & 3.63 \\
\hline 11.5 & 3.455 & 2.865 \\
\hline 12.0 & 6.950 & 6.362 \\
\hline 12.5 & 4.841 & 4.25 \\
\hline 13.0 & 2.451 & 2.32 \\
\hline 13.5 & 3.441 & 3.00 \\
\hline & & \\
\hline
\end{tabular}

$*$ The values given in the table are the mean of the triplicate values obtained. 


\section{BIOGRAPHIES}

Mrs. Sangeeta Gupta, M.Sc. She is currently a Ph.D scholar in the Department of Applied Chemistry affiliated to Rani Durgawati Vishwavidyalaya, Jabalpur (India) 482011 under the guidance of Dr. S.K.Shrivastava and Dr. Manjul Shrivastava. Her research includes natural product. She has four publications in her credit.

Dr. S. K. Shrivastava, M.Sc, Ph.D. He is Professor and Head of the Department of Applied Chemistry, Jabalpur Engineering College Jabalpur, (India) 482011. His research includes natural product. He has 79 publications in his credit. He has guided $16 \mathrm{Ph} . \mathrm{D}$. students.

Dr. Manjul Shrivastava, M.Sc, Ph.D, She is Professor and Head of the Department of Chemistry, Govt. Home Science College Jabalpur, (India) 482002. Her research includes natural product. She has 24 publications in her credit. She has guided 7 Ph.D. students. 